\title{
Evaluasi Program Parenting \\ Pada Pendidikan Anak Usia Dini (PAUD) Di Kota Mataram
}

\author{
Maimun*
}

\begin{abstract}
The objective of this research was to understand comprehensively about the enforceability of parenting program on early childhood education (PAUD) in Mataram pre-schools. The study applies qualitative approach the focuses on evaluation in preshool education in Mataram. The data were collected through interviews, observation, documentation, and questionnaire. This Study shows that (1) the background of the parenting program implementation was lack of parents' supports of child education; (2) the implementation of parenting program in pre-shools has fulfilled the requirements laid down in the guideline book; (3) most of pre-school institutions have implemented parenting program in accordance with the technical guideline book; and (4) the majority of parents' understandings of child nutrition, treatment, upbringing, and protection have signivicantly increased upon the implementation of the program.
\end{abstract}

Keywords: Program evaluation, parenting program, early childhood education.

Abstrak: Penelitian ini betujuan untuk memahami secara komprehensif tentang keterlaksanaan program parenting pada Pendidikan Anak Usia Dini (PAUD) di Kota Mataram. Penelitian ini menggunakan pendekatan kualitatif dengan objek evaluasi adalah program parenting pada PAUD se Kota Mataram. Data dikumpulkan menggunakan teknik wawancara, Observasi, dokumentasi, dan angket. Hasil analisis data menunjukkan: (1) Pelaksanaan program parenting dilatarbelakangi oleh lemahnya partisipasi orang tua terhadap pendidikan anak. (2) Pogram parenting yang dilaksanakan di lembaga PAUD telah memenuhi syarat sesuai yang di gariskan pada buku petujuk teknis, (3) Sebagian besar lembaga PAUD telah melaksanakan program parenting sesuai dengan buku petujuk teknis. (4) Hasil pelaksanaan program parenting menunjukkan bahwa pemahaman sebagian besar orang tua tentang gizi, kesehatan, perawatan, pengasuhan, pendidikan,dan perlindungan anak semakin baik.

Kata Kunci: Evaluasi Program, Program Parenting, Pendidikan Anak Usia Dini.

\section{PENDAHULUAN}

Manusia adalah makhluk beradab yang diciptakan Tuhan. Makhluk yang condong kepada kebenaran dan kebaikan. Sebagai makhluk beradab, manusia memerlukan tuntunan untuk membuatnya konsisten terhadap hakekat dirinya. Pendidikan adalah salah satu wadah untuk menjadikan manusia berada dalam keadaban. Pendidikan merupakan suatu yang niscaya dalam kehidupan manusia dalam mewujudkan dirinya sebagai makhluk beradab dan berbudaya. Permulaan wahyu yang diturunkan Allah kepada Nabi Muhammad SAW dalam al-quran surat Al Alaq ayat 1-5 yakni "Bacalah dengan menyebut nama Tuhanmu yang menciptakan, Dia telah menciptakan manusia dari segumpal darah, bacalah dan Tuhanmulah yang Maha mulia,

\footnotetext{
* Maimun, Fakultas Ilmu Tarbiyah dan Keguruan IAIN Mataram, Jln. Gadjah Mada No. 100 Mataram NTB, Telp. (0370)620783,620784,e-mail: maimun05@ymail.com
} 
yang mengajar (manusia) dengan pena, Dia mengajar manusia apa yang tidak diketahuinya."(Departemen Agama RI, 2006: 479).

Perintah membaca dalam ayat di atas dapat dijadikan bukti betapa pendidikan itu sangat diperlukan dalam kehidupan manusia.

Pendidikan sebagai sesuatu yang amat diperlukan dalam kehidupan manusia tidak boleh terhenti pada usia tertentu. Pendidikan harus berjalan mengikuti usia manusia sebagaimana disabdakan Nabi Muhammad SAW "Tuntutlah ilmu itu semenjak buaian hingga liang lahat". Artinya pendidikan itu berjalan sepanjang umur manusia (life long learning).

Berpijak dari konsep bahwa pendidikan berlangsung sepanjang usia manusia, maka sejatinya manusia memperoleh pembelajaran yang sesuai dengan tingkat dan situasi pertumbuhan dan perkembangannya. sebagaimana pesan Nabi SAW; "Didiklah anakmu sesuai zamannya, karena dia lahir pada zamannya, bukan pada zaman kamu." Dalam hal ini orang tua setidaknya harus memahami hal ini, karena merekalah yang mengawal kehidupan anaknya semenjak lahir. Dalam konteks yang lain Nabi Muhammad SAW bersabda dalam salah satu haditsnya; "Manusia lahir dalam keadaan suci, orang tuanyalah yang membuat dia Yahudi, Nasrani, atau Majusi."
Peran orang tua menjadi utama dan pertama di dalam proses pendidikan anakanaknya. Karena orangtualah yang mestinya paling mengerti bagaimana sifat dan potensi yang dibawa anak-anaknya, termasuk kesenangan atau kesukaannya, apa saja yang anaknya tidak sukai, perubahan dan perkembangan karakter serta kepribadian anakanaknya, termasuk rasa malu, takut, sedih dan gembira. Idealnya orangtualah yang pertama kali memahaminya, sehingga dalam hal ini, keluarga merupakan salah satu tempat sosialisasi pertama bagi anak-anak untuk mempelajari semua hal (socialization agent). (Andayani dan Koentjoro, 2012: 51).

Anak yang pada dasarnya lahir dalam keadaan tidak berdaya namun memiliki potensi yang bisa dikembangkan yang membutuhkan arahan dan bimbingan orang dewasa yakni orang tua untuk mengembangkan potensi tersebut. Jadi anak sesungguhnya memiliki ketergantungan yang sangat tinggi kepada orang tua terutama pada usia pra sekolah yakni Pendidikan Anak Usia Dini (PAUD) dan Taman Kanak-kanak (TK).

Kesadaran dan cara pandang anak terhadap dirinya sendiri bergantung kepada perlakuan dan pergaulan orang tuanya di masa kecil. (Basya, 2011: 10). Anak-anak yang dibiarkan berkembang menurut kata hatinya tanpa kepedulian orang tua ibarat menambah rumput liar dan semak belukar di depan rumah, artinya anak akan tumbuh dan berkembang 
seperti manusia yang tidak punya pengasuh. Tidak sepantasnya orang tua yang telah melahirkan anak-anak sendiri membiarkan anaknya bertumbuh dan berkembang sendiri tanpa pengasuhan yang baik. Orang tua dalam hal ini harus bertanggung jawab dalam pengasuhan anak, karena orang tua merupakan pendidik dasar yang akan menentukan kualitas kehidupan anak-anaknya kelak. (Gichara, 2013: 19). Di samping itu orang tua juga merupakan cermin bagi anak dalam membangun watak, karena watak anak terbentuk melalui contoh yang orang tua katakan dan kerjakan, serta keselarasan antara keduanya. (Noe'man, 2012: xiv)

Orang tua dan lembaga pendidikan merupakan dua unsur yang memiliki keterkaitan yang kuat satu sama lain. Dalam hal mendidik, orang tua tidak dapat menyerahkan kepercayaan seluruhnya kepada guru di lembaga PAUD, artinya orang tua harus banyak berkomunikasi dengan gurunya, begitu juga sebaliknya. Orang tua mendidik anaknya di rumah, dan di PAUD untuk mendidik anak diserahkan kepada pihak guru. Sehingga sudah seharusnya orang tua dilibatkan dalam penyelenggaraan pendidikan di PAUD.

Usia dini merupakan periode perkembangan yang sangat penting dalam kehidupan manusia. Pada masa ini, seluruh instrumen besar manusia terbentuk, bukan hanya kecerdasan saja tetapi seluruh kecakapan psikis. Para ahli menamakan periode ini (0-6 tahun) sebagai usia emas perkembangan, sehingga peran stimulasi lingkungan yang kondusif dan dilakukan dengan cara bermain akan dapat mengembangkan pertumbuhan otak dan seluruh potensi anak. (Kementerian Pendidikan Nasional, 2012: i). Undang-Undang Nomor 20 Tahun 2003 tentang Sistem Pendidikan Nasional, secara tegas menyatakan bahwa "Pendidikan anak usia dini adalah suatu upaya pembinaan yang ditujukan kepada anak sejak lahir sampai dengan usia enam tahun yang dilakukan melalui pemberian rangsangan pendidikan untuk membantu pertumbuhan dan perkembangan jasmani dan rohani agar anak memiliki kesiapan dalam memasuki pendidikan lanjut". (UU Sisdiknas, 2003: 14). Selanjutnya dinyatakan pula bahwa pendidikan anak usia dini dapat diselenggarakan pada jalur formal (Taman Kanak-kanak/ Raudhathul Athfal), jalur nonformal (Taman Penitipan Anak, Kelompok Bermain, dan bentuk lain yang sederajat), dan pada jalur informal (melalui

Kementerian Pendidikan Nasional telah mengeluarkan Peraturan Menteri Pendidikan Nasional Nomor 36 Tahun 2010 tentang Organisasi dan Tata Kerja Kementerian Pendidikan Nasional, dalam peraturan tersebut ditegaskan bahwa pembinaan PAUD baik formal, nonformal, maupun informal, berada di bawah binaan Direktorat Jenderal Pendidikan Anak Usia Dini, Nonformal dan Informal (Ditjen PAUDNI), yang secara teknis dilaksanakan oleh Direktorat Pembinaan 
Pendidikan Anak Usia Dini. (Kemetrian Pendidikan Nasional, Direktorat Pembinaan Pendidikan Anak Usia Dini, 2011: i).

Pendidikan Anak Usia Dini adalah jenjang pendidikan sebelum jenjang pendidikan dasar yang merupakan suatu upaya pembinaan yang ditujukan bagi anak sejak lahir sampai dengan usia enam tahun yang dilakukan melalui pemberian rangsangan pendidikan untuk membantu pertumbuhan dan perkembangan jasmani dan ruhani agar anak memiliki kesiapan dalam memasuki pendidikan lebih lanjut yang diselenggarakan pada jalur formal, nonformal, dan informal. (Hasan, 2012: 15)

Rentangan anak usia dini menurut Undang-Undang RI Nomor 20 Tahun 2003 tentang Sistem Pendidikan Nasional Pasal 28 dijelaskan bahwa pendidikan anak usia dini diselenggarakan sebelum jenjang pendidikan dasar pada jalur pendidikan formal berbentuk taman kanak-kanak (TK), raudatul athfal (RA), dan pada jalur pendidikan nonformal berbentuk kelompok bermain $(\mathrm{KB})$, taman penitipan anak (TPA) atau bentuk lain yang sederajat. Sementara menurut kajian rumpun keilmuan PAUD dan penyelenggaraannya di beberapa negara, PAUD dilaksanakan sejak usia 0-8 tahun berupa Infant (usia 0-1 tahun), Toddler (usia 2-3 tahun), preschool/kindergarten children (usia 3-6 tahun), dan Early Primary School/SD kelas awal (usia 6-8 tahun). Tujuannya adalah untuk mengembangkan pengetahuan dan pemahaman orang tua dan guru serta pihak-pihak yang terkait dengan pendidikan dan perkembangan anak usia dini. Sedangkan tujuan yang ingin dicapai, adalah: (1) dapat mengidentifikasi perkembangan fisiologis anak usia dini dan mengaplikasikan hasil indetifikasi tersebut dalam pengembangan fisiologis yang bersangkutan; (2) dapat memahami perkembangan kreativitas anak usia dini dan usaha-usaha yang terkait dengan pengembangannya; (3) dapat memahami kecerdasan jamak dan kaitannya dengan perkembangan anak usia dini; (4) dapat memahami arti bermain bagi perkembangan anak usia dini; dan (5) dapat memahami pendekatan pembelajaran dan aplikasinya bagi pengembangan anak usia kanak-kanak.

Selain itu, tujuan pendidikan anak usia dini adalah; (1) untuk membentuk anak Indonesia yang berkualitas, yaitu anak yang tumbuh dan berkembang sesuai dengan tingkat perkembangannya sehingga memiliki kesiapan optimal dalam memasuki pendidikan dasar serta mengarungi kehidupan dimasa dewasa; (2) untuk membantu menyiapakan anak mencapai kesiapan belajar (akademik) di sekolah; (3) intervensi dini dengan memberikan rangsangan sehingga dapat menumbuhkan potensi-potensi yang tersembunyi (hidden potency) yaitu dimensi perkembangan anak (bahasa, intelektual, emosi, sosial, motorik, konsep diri, minat dan bakat; (4) melakukan deteksi dini terhadap kemungkinan terjadinya gangguan 
dalam pertumbuhan dan perkembangan potensipotensi yang dimiliki anak.

Untuk mewujudkan tujuan tersebut pemerintah telah menetapkan kebijakan pengembangan PAUD melalui pendekatan "Holistik Integratif", yaitu PAUD yang tidak hanya menekankan aspek pendidikan semata, tetapi mencakup juga aspek pelayanan gizi, pelayanan kesehatan, pengasuhan, dan perlindungan anak, pada tahun 2011 Pemerintah terus mendorong dan memperluas kesempatan bagi masyarakat untuk berpartisipasi dalam mengembangkan layanan pendidikan anak usia dini melalui pendirian berbagai jenis satuan pendidikan anak usia dini. (Direktorat Pembinaan Pendidikan Anak Usia Dini, 2011: iv)

Berkembangnya lembaga PAUD dalam berbagai bentuk layanan seperti: Taman KanakKanak (TK), Taman Penitipan Anak (TPA), Kelompok Bermain (KB), dan Satuan PAUD Sejenis (SPS) menunjukkan semakin meningkatnya kesadaran masyarakat tentang pentingnya pendidikan yang sesuai dengan tahap perkembangan sejak usia dini. Namun demikian lembaga PAUD yang demikian pesat pertumbuhannya tidak dapat menggantikan peran pendidikan di dalam keluarga. (Direktorat Pembinaan Pendidikan Anak Usia Dini, 2011: iv)

Pendidikan di dalam keluarga atau lebih popular dengan sebutan parenting adalah upaya orang tua yang diaktualisasikan pada penataan lingkungan sosial, lingkungan budaya, suasana psikologis serta perilaku yang ditampilkan pada saat terjadinya pertemuan dengan anak-anak. (Shohib, 1998: 21). Menurut Thoha, parenting merupakan suatu cara terbaik yang ditempuh oleh orang tua dalam mendidik anak sebagai perwujudan dari rasa tanggung jawab kepada anak. (Thoha, 2004: 22). Sementara Megawangi menjelaskan bahwa parenting merupakan proses menciptakan suasana kegiatan belajar mengajar yang menekankan kehangatan bukan ke arah suatu pendidikan satu arah atau tanpa emosi. ( Megawangi, 2007: 13)

Kegiatan parenting pada umumnya dilakukan oleh orang tua kandung kepada anakanaknya. Secara lebih luas program parenting juga dapat dimaknai sebagai bentuk kegiatan informal yang dilakukan untuk menyelaraskan kegiatan-kegiatan pengasuhan dan pendidikan anak antara di kelompok bermain atau di PAUD dan di rumah.

Memahami pentingnya kesesuaian program pengasuhan anak di rumah dan kegiatan pembelajaran di lembaga PAUD, maka diharapkan setiap lembaga PAUD memfasilitasinya melalui penyelenggaraan Program parenting atau PAUD Berbasis Keluarga yang merupakan pemberdayaan untuk memperkuat peran keluarga sebagai lingkungan yang paling berpengaruh terhadap pertumbuhan dan perkembangan anak. Untuk keperluan tersebut Direktorat Pembinaan Pendidikan Anak Usia Dini menerbitkan Pedoman 
Penyelenggaraan Pendidikan Anak Usia Dini Berbasis Keluarga. (Kementerian Pendidikan Nasional, 2012: iii)

Di Kota Mataram terdapat 241 lembaga PAUD, baik dalam bentuk lembaga formal maupun nonformal (TK, RA, KB, dan TPA). Berdasarkan hasil studi pendahuluan pada tanggal 6 - 8 Maret 2014 menunjukkan PAUD yang berbentuk lembaga formal secara keseluruhan sudah menerapkan program parenting, sementara PAUD dalam bentuk nonformal hanya 21 lembaga yang sudah menerapkan program parenting. Juga ditemukan bahwa program parenting yang telah berlangsung sejak tahun 2012 sampai sekarang belum memperlihatkan hasil yang optimal dilihat dari indikator-indikator ketercapaian program, yakni pada masalah gizi, kesehatan, perawatan, pengasuhan, pendidikan, dan masalah perlindungan anak. Indikator-indikator tersebut merupakan hal yang mutlak dicapai oleh semua lembaga PAUD yang menyelenggarakan program parenting. Untuk itu merupakan suatu hal yang sangat perlu jika ada upaya untuk mengevaluasi keterlaksanaan program ini.

Beberapa model evaluasi dapat digunakan untuk mengevaluasi penyelenggaraan program parenting. Pemilihan model evaluasi yang tepat akan sangat mempengaruhi hasil evaluasi yang dilakukan, sehingga hasil evaluasi tersebut dapat memberikan kontribusi yang positif bagi para pelaksanaan program. Model evaluasi terpadu antara komponen masukan, proses, dan keluaran dapat digunakan dalam mengevaluasi penyelenggaraan program parenting. Salah satu model evaluasi yang dapat menganalisis tingkat keberhasilan penyelenggaraan program parenting adalah model yang dikembangkan oleh Stufflebeam yaitu model CIPP (Contexs, Input, Process, dan Product).

Berdasarkan karakteristik permasalahan yang telah diungkapkan tersebut di atas, maka sangat perlu dilakukan penelitian secara mendalam berupa evaluasi program penyelenggaraan program parenting di Kota Mataram.

\section{METODOLOGI PENELITIAN}

Penelitian ini merupakan penelitian evaluasi program dengan pendekatan kualitatif yang dilaksanakan mulai bulan April sampai bulan September 2014. Secara umum penelitian ini mendeskripsikan efektifitas keterlaksanaan program parenting pada PAUD di Kota Mataram.

Model evaluasi yang digunakan adalah CIPP (Contexs, Input, Process, dan Product). Model ini memuat empat poin penting yang diaplikasikan dalam proses penelitian di lembaga PAUD di Kota Mataram NTB, yakni (1) Komponen konteks, dalam penelitian ini dimaksudkan adalah landasan formil dan situasi atau latar belakang diperlukannya pelaksanaan program parenting pada lembaga PAUD di Kota Mataram; (2) Komponen input, dalam 
penelitian ini meliputi: Tujuan pelaksanaan program, sasaran pelaksanaan program, pengelolaan program, pendekatan yang digunakan, bentuk program, Narasumber, pendampingan, peran lembaga PAUD, Metode yang digunakan, media yang digunakan, dan materi yang diberikan dalam membelajarkan orang tua; (3) Komponen proses yang mana dalam penelitian ini dibagi dua tahapan, yakni tahap pesiapan program meliputi; Sosialisasi program parenting, pembentukan pengurus program parenting, penyamaan persepsi, identifikasi kebutuhan belajar, penentuan tempat dan waktu, dan penyusunan program dan jadwal kegiatan. Dan tahap pelaksanaan program yang ditandai dengan dilaksanakknnya beberapa kegiatan, di antaranya: Kegiatan pertemuan orang tua (kelas orang tua), keterlibatan orang tua di kelas anak, keterlibatan orang tua dalam acara bersama, hari konsultasi orang tua, dan kunjungan rumah; dan (4) Komponen produk, yakni hasil pelaksanaan program parenting pada lembaga PAUD dalam wujud pemahaman orang tua meningkat terkait dengan gizi, kesehatan, perawatan, pengasuhan yang bermutu, penddidikan yang baik, dan perlindungan anak.

Pengumpulan data menggunakan studi dokumen, wawancara, observasi, dan angket dengan instrumen yang sudah divalidasi oleh pakar di bidang PAUD dan Evaluasi, validasi panelis, Promotor dan co-Promotor. Adapun teknik analisis data pada penelitian ini menggunakan model Miles dan Huberman dengan tahapan-tahapan sebagai berikut: (1) Pengumpulan Data; (2) Reduksi Data yaitu proses merangkum, dan memilih hal-hal yang pokok; (3) Display Data yakni proses penyajian data; dan (4) Menarik Kesimpulan dan Verifikasi Data.

\section{HASIL PENELITIAN}

Program parenting merupakan suatu bentuk kegiatan yang bertujuan memberikan pemahaman kepada orang tua terkait dengan tumbuh kembang anak. Dalam melakukan evaluasi terhadap program parenting, peneliti menggunakan model CIPP (Contexts Input Process Product). Terdapat empat poin penting yang menjadi sasaran evaluasi sesuai dengan model CIPP, yakni evaluasi terhadap komponen konteks yang menyangkut landasan formil dan latar belakang dilaksanakannya program, komponen input menyangkut perencanaan program parenting, komponen proses menyangkut pelaksanaan program parenting, dan komponen produk menyangkut hasil program parenting. Hasil evalusi dari setiap kompenen dideskripsikan berdasarkan data yang peneliti peroleh dari hasil observasi, wawancara, angket, dan telaah dokumen sebagai berikut:

\section{Komponen Conteks berupa Landasan Formal Pelaksanaan Program Parenting pada Lembaga PAUD di Kota Mataram}

Pendidikan Anak Usia Dini merupakan bagian dari pencapaian tujuan pendidikan 
nasional yang diatur dalam Undang Undang RI Nomor 20 Tahun 2003 tentang "Sistem Pendidikan Nasional” Bab 1 Pasal 1 Butir 14 dinyatakan bahwa Pendidikan Anak Usia Dini adalah suatu upaya pembinaan yang ditujukan kepada anak sejak lahir sampai dengan usia 6 tahun yang dilakukan melalui pemberian rangsangan pendidikan untuk membantu pertumbuhan dan perkembangan jasmani dan rohani agar anak memiliki kesiapan dalam memasuki pendidikan lebih lanjut. Sementara didalam Undang Undang RI Nomor 23 Tahun 2002 tentang "Perlindungan Anak" Pasal 9 Ayat 1 dinyatakan bahwa setiap anak berhak memperoleh pendidikan dalam rangka pengembangan pribadinya dan tingkat kecerdasannya sesuai dengan minat dan bakatnya.

Legimitasi dari undang undang di atas diperkuat pula dengan Peraturan Menteri Negara Pemberdayaan Perempuan dan Perlindungan Anak Republik Indonesia Nomor 13 Tahun 2010 Tentang "Petunjuk Teknis Kabupaten/Kota Layak Anak di Desa/Kelurahan" dinyatakan bahwa setiap anak yang dilahirkan harus dipertangung jawabkan. Secara individu anak merupakan tanggung jawab keluarga atau orang tuanya di dunia maupun di akhirat. Baik atau buruknya kualitas anak ditentukan oleh orang tua anak tersebut.

Partisipasi orang tua dalam tumbuh kembang anak sangat membantu didalam perkembangan belajar anak. Ketika orang tua berperan aktif dalam proses pembelajaran, maka akan berdampak positif bagi perkembangan belajar anaknya dan akan terbangun semangat belajar anak secara psikis, sehingga mudah dalam menerima pelajaran, mengingat pendidikan bukan hanya mencetak lulusan yang memiliki kemampuan akademik melainkan juga akhlak, moral dan spiritual, maka orang tua juga berperan sebagai penanggung jawab utama pendidikan anak.

Peran serta keluarga, sekolah dan masyarakat secara bersama-sama adalah sangat niscaya dalam rangka mewujudkan tujuan pendidikan. Oleh karenanya pendidikan bukan menjadi tanggung jawab tunggal sekolah tetapi tanggung jawab bersama antara orang tua, masyarakat, lembaga pendidikan, dan pemerintah.

\section{Komponen Conteks berupa Latar Belakang Perlunya dilaksanakan Program Parenting pada Lembaga PAUD di Kota Mataram}

Pelaksanaan program parenting pada lembaga PAUD dilatarbelakangi oleh lemahnya partisipasi orang tua terhadap pendidikan anak usia dini, hal ini terlihat dari kondisi sebagian besar orang tua belum memahami pentingnya pendidikan bagi anak pada usia dini.

Selain persepsi orang tua yang lemah yang menjadi alasan dilaksanakannya program parenting pada lembaga PAUD, penyelenggara juga berkepentingan untuk menjalin kerjasama 
dengan orang tua, sehingga apa yang telah dilaksanakankan oleh guru di sekolah bisa diterapkan oleh orang tua di rumah, mengingat waktu anak berada di sekolah relatif lebih singkat dibanding waktu di rumah, dengan begitu apa yang menjadi tujuan pembelajaran di sekolah dapat dengan mudah dicapai.

Beriku disajikan hasil angket dalam bentuk diagram terkait latar belakang diperlukannya penyelenggaraan program parenting pada PAUD di Kota Mataram:

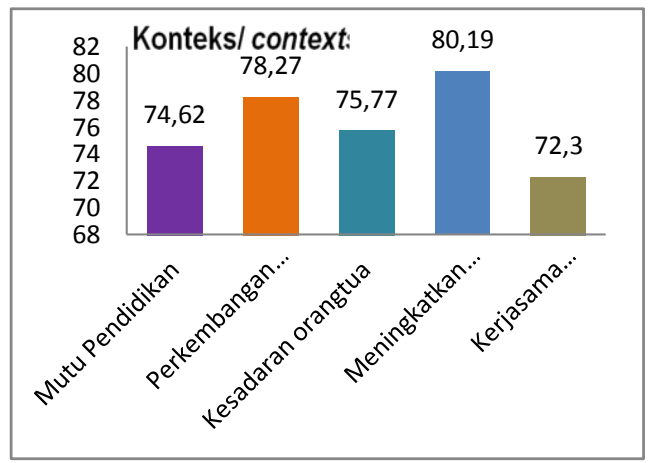

Gambar 1

Diagram Latar Belakang perlunya Program Parenting pada PAUD

Situasi yang mempengaruhi perlunya pelaksanaan program parenting terhadap orang tua dan keluarga, hasil angket program parenting meningkatkan mutu pendidikan anak $74,62 \%$, Orangtua melihat perkembanga pendidikan anak melalui parenting 78,27 \% Kesadaran orangtua meningkat sebagai pendidik yang utama 75,77\%, Meningkatnya sikap kelurga dalam melakukan kesehatan 80,19\%, dan Orangtua menumbuhkan kerjasama terhadap penyelenggara pendidikan $72,30 \%$.
3. Komponen Input berupa Perencanaan Program Parenting pada Lembaga PAUD di Kota Mataram

Pogram parenting yang dilaksanakan di lembaga PAUD ditinjau dari aspek perencanaan telah memenuhi standar yang digariskan pada buku petujuk teknis, yakni telah dilaksanaknnya kegiatan-kegiatan berikut: (a) Tujuan pelaksanaan program parenting pada lembaga PAUD adalah terwujudnya pelaksanaan PAUD berbasis keluarga dengan ditandai oleh adanya partisipasi orang tua terhadap pendidikan anak usia dini, terjalinnya kerjasama yang baik antara guru dan orang tua, sehingga orang tua memahami apa yang dilakukan oleh guru di sekolah terhadap anak dan orang tua dapat melakukan hal yang sama dalam mendidik anaknya di rumah; (b) Sasaran pelaksanaan program parenting pada lembaga PAUD di kota Mataram adalah orang tua, paman, bibi, kakek, nenek, pembantu rumah tangga, dan lembaga terkait, meliputi: Komite, Tenaga Pendidik, Dikpora Kota Mataram; (c) Pengelolaan program parenting dilakukan melalui rapat koordinasi dengan musyawwarah untuk mencapai mufakat; (d) Pendekatan yang digunakan oleh pengelola dalam program parenting adalah pendekatan andragogi (caracara pembelajaran orang dewasa), dengan memusatkan perhatian pada pemahaman yang terkait dengan pendidikan anak; (e) Bentuk program parenting yang dilakukan pada lembaga PAUD, antara lain: orang tua terlibat 
dalam kelas anak, kelas orang tua, acara bersama, dan hari konsultasi; (f) Narasumber dalam pelaksanaan program parenting berasal dari dalam dan luar lembaga. Dari dalam lembaga seperti guru dan kepala sekolah, sedangkan dari luar lembaga seperti Dokter, Tokoh masyarakat (Tuan Guru/Ustadz), PKBI (Perkumpulan Keluarga Berencana Indonesia), Praktisi pendidikan dari Diknas Kota Mataram, praktisi IKIP Mataram, dan Psikolog. Akan tetapi masih ada PAUD yang belum pernah menggunakan narasumber dari luar lembaga PAUD; (g) Bentuk pendampingan dilakukan oleh HIMPAUDI, IKTKI, PKG, Dinas Sosial, BKKBN, dan Dinas Kesehatan dan IGTKI dengan cara melakukan pertemuan sekali dalam sebulan dalam rangka membahas/berdiskusi tentang informasi-informasi mengenai pentingnya parenting, administrasi dan peningkatan kualitas pendidik, seperti membuat alat peraga dan bagaimana menangani anakanak yang bermasalah dalam belajarnya. Namun ada juga PAUD yang belum mendapatkan pendampingan; (h) Peran Lembaga PAUD dalam menunjang pelaksanaan program parenting antara lain: Sebagai perantara/mediator pengelola dan orang tua, menyediakan dana, sarana, prasarana, tempat dan waktu, mendatangkan narasumber sesuai yang dibutuhkan, memberikan berbagai informasi ke orang tua, mengawasi dan memberikan masukan kepada pengelola jika ada program yang belum dilaksanakan; (i) Metode yang digunakan dalam pelakasanaan program parenting masih dominan Metode Ceramah, tetapi juga diselingi dengan Metode Tanya Jawab, Metode Diskusi, dan Metode Keteladanan/Didactic Character. Metode bermain peran/simulasi, Metode kunjungan lapangan, dan Metode praktek belum digunakan secara maksimal; (j) Media yang digunakan oleh pengelola dalam menyampaikan informasi kepada orang tua antara lain: Laptop, LCD screen, VCD, Audio/kaset, Alat Peraga, CD Interaktif, Gambar-gambar, Kartu Bergambar, Buku, Makalah, Bulletin, dan Tabloid. Namun ada satu lembaga yang belum menggunakan media dalam pembelajaran parenting; dan $(\mathrm{k})$ Materi yang diberikan dalam program parenting antara lain tentang: Agama, pentingnya memelihara kesehatan anak, Cara melakukan pengasuhan, Cara mendidik anak dengan tidak berkata kasar, Cara menyaiapkan dan memebrika gizi yang cukup dan seimbang bagi anak, Cara merawat anak, Cara melakukan upaya perlindungan bagi anak, Cara melakukan komunikasi yang efektif dengan anak, Cara memanfaatkan limbah, Cara mengatasi pengaruh games pada anak, cara mengatasi anak yang cepat bosan dalam belajar, dan Cara mengatur jam istirahat anak. Berikut disajikan hasil angket terkait dengan perencanaan program parenting: 


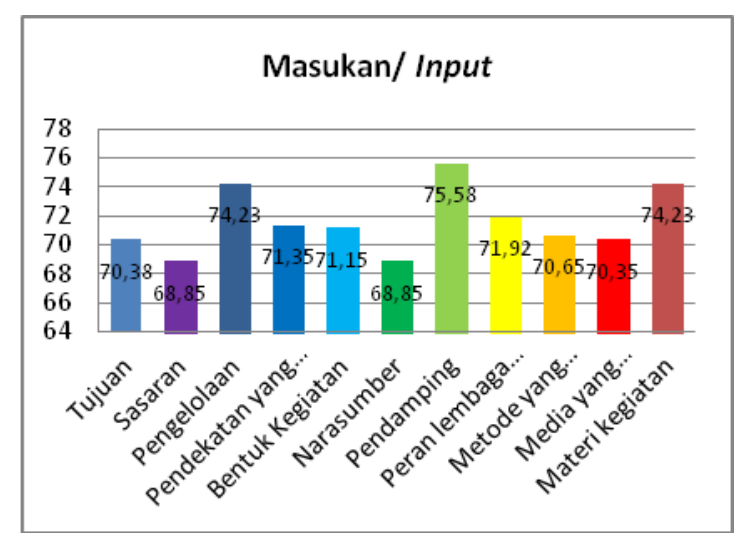

Gambar 2

\section{Diagram Perencanaan Program Parenting}

Hasil angket komponen masukan/Input program parenting Tujuan program parenting pada PAUD di Kota Mataram 70,38\%, sasaran program parenting pada PAUD di Kota Mataram 68,85\%, Koordinasi Pengelolaan program Parenting dengan Penyelenggara PAUD di Kota Mataram 74,23\%, Pendekatan yang digunakan didalam mempelajari orang tua dalam melaksanakn program parenting pada PAUD di Kota Mataram 71,35\%, Bentuk kegiatan program parenting pada PAUD di Kota Mataram 71,15\%, Narasumber dalam membelajarkan orangtua program parenting pada PAUD di Kota Mataram 68,85\%, Bentuk Pendampingan program parenting pada PAUD di Kota Mataram 75,58\%, Peran lembaga PAUD dalam melaksanaan program parenting pada PAUD di Kota Mataram 71,92\%, Metode yang digunakan dalam pelaksanaan program parenting untuk meningkatkan mutu pendidikan anak 70,65\%, Media yang digunakan dalam pelaksanaan program parenting pada PAUD di Kota Mataram 70,35\%, Materi yang diberikan dalam melaksanakn program parenting pada PAUD di Kota Mataram 74,23\%.

\section{Komponen Proses berupa Pelaksanaan Program Parenting pada Lembaga PAUD di Kota Mataram}

Proses pelaksanaan program parenting pada lembaga PAUD dilakukan melalui dua tahapan, yakni tahap pesiapan program dan tahap pelaksanan program. Tahap persiapan program meliputi; Sosialisasi program parenting, pembentukan pengurus program parenting, penyamaan persepsi, identifikasi kebutuhan belajar, penentuan tempat dan waktu, dan penyusunan program dan jadwal kegiatan. Sedangkan tahap pelaksanaan progran meliputi beberapa kegiatan, di antaranya: Kegiatan pertemuan orang tua (kelas orang tua), keterlibatan orang tua di kelas anak, keterlibatan orang tua dalam acara bersama, hari konsultasi orang tua, dan kunjungan rumah. Berikut dipaparkan hasil penelitian terkait dengan proses pelaksanaan program prenting: (a) Sosialisasi Program PAUD dilakukan oleh penyelenggara di awal tahun atau ketika orang tua baru mendaftarkan anak ke lembaga PAUD, baik dengan cara berkomunikasi langsung dengan orang tua pada saat mengantar atau menjemput anak, maupan dengan cara tidak langsung yakni mengirim surat kepada orang tua siswa dan melalui buku penghubung; (b) Pembentukan pengelola program parenting dilakukan setelah ada kesepakatan dengan guru- 
guru untuk melakasnakan program parenting biasanya dilakukan di awal tahun melalui rapat yang dihadiri oleh penyelenggara, guru dan orang tua siswa; (c) Penyamaan persepsi dilakukan agar persepsi orang tua dan guru sama, biasanya melalui pertemuan dengan orang tua di awal tahun ajaran dengan cara; Pengelola menyampaikan program dan kemudian ditanggapi lalu dikoreksi dan diberi masukan oleh orang tua; (d) Identifikasi kebutuhan belajar dilakukan melalui: First record atau semacam angket yang isinya adalah latar belakang keluarga, masalah anak, masalah orang tua, Menyampaikan kepada orang tua tentang apa saja kegiatan yang akan dilakukan, dan Membagikan angket kepada orang tua di awal ketika mereka mengikuti program parenting; (e) Penentuan tempat dan waktu kegiatan parenting dilakukan secara bersamasama melalui rapat pada tahap awal sebelum memulai kegiatan; (f) Penyusunan program dan jadwal kegiatan dilakukan secara bersama-sama antara pengelola dan orang tua siswa tentunya setelah pengelola terbentuk; (g) Kegiatan pertemuan orang tua dalam program parenting dilakukan secara rutin tiap sebulan sekali sesuai jadwal yang telah dibuat oleh pengelola; (h) Keterlibatan orang tua di kelas anak pada program parenting dilakukan berdasarkan perminataan dari guru dan dengan cara ikut mengajar sesuai tema dan profesi; Keterlibatan orang tua dalam acara bersama seperti acara makan bersama, bermain bersama, outbond bersama, bakti sosial, gotong royong, saat menyambut bula Ramadan, Idul Adha, lomba antara orang tua dan anak,dan pada saat ada salah satu anak yang berulang tahun, pelaksanaan acaranya dilakukan di lembaga PAUD; (j) Hari konsultasi orang tua pada beberapa lembaga PAUD dilakukan setiap hari aktif sekolah,sedangkan pada beberapa lembaga PAUD lainnya hari konsultasi dilakukan sesuai dengan jadwal yang telah disepakati sebelumnya, seperti satu bulan sekali dan tiap tiga bulan sekali. Orang tua berkonsultasi dengan cara menanyakan perkembangan anaknya ke guru. Adapuan materi/hal-hal yang dikonsultasikan orang tua seperti masalah pribadi tentang pengasuhan anak, bagaimana menangani anak-anak yang bermasalah, anak yang sakit, dan anak yang tidak mau sekolah; dan (k) Kunjungan rumah yang dilakukan oleh pengelola program parenting melibatkan orang tua terutama jika ada salah satu siswa yang sakit, jika orang tua anak tidak bisa dihubungi melalui telfon, dan dilakukan secara personal oleh guru saja tidak melibatkan orang tua lain, dengan tujuan agar orang tua yang dikunjungi bisa lebih terbuka bercerita tentang masalah yang ia hadapi.

Data hasil angket terkait dengan pelaksanaan program parenting disajikan dalam gambar Diagram berikut: 


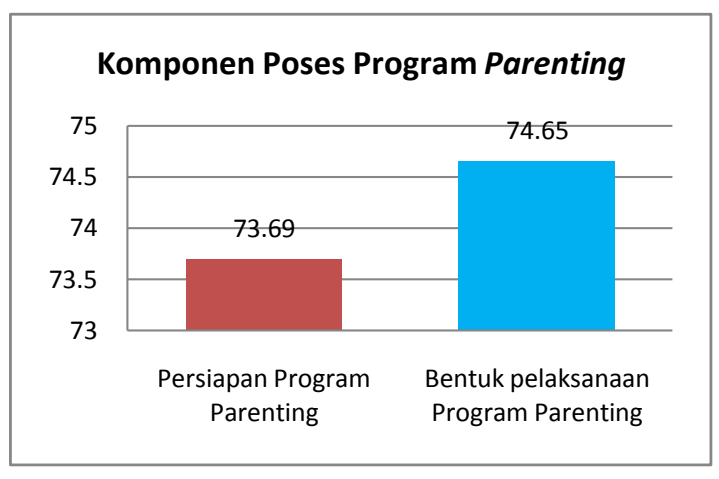

Gambar 3

\section{Diagram Pelaksanaan Program Parenting}

Hasil angket pada pelaksanaan program parenting menunjukkan keterlaksanaan pada program persiapan $73,69 \%$, sedangkan dalam bentuk pelaksanaan program $74,65 \%$.

\section{Komponen Produk berupa Hasil Program Parenting pada Lembaga PAUD di Kota Mataram}

Program parenting yang telah dilaksanakan di lembaga PAUD dapat dilihat hasilnya pada hal-hal berikut: (a) Meningkatnya pemahaman orang tua tentang gizi anak, hal ini dapat dilihat dari: Orang tua sudah menerapakan pentingnya memelihara gizi anak dengan mencari tahu makanan-makanan apa yang berbahaya dikonsumsi oleh anak, Orang tua mematuhi peraturan di sekolah, seperti tidak diperbolehkan membawa snack dan permen ke sekolah, Orang tua memberikan gizi yang cukup, seperti makanan yang dibawa oleh anak ke sekolah selalu nasi, sayur, dan lauk yang dibuatkan dari rumah, walaupun ada sebagian yang masih membawa ciki-ciki; Meningkatnya pemahaman orang tua tentang kesehatan anak, hal ini dapat dilihat dari: Orang tua membiasakan anak untuk membiasakan cuci tangan dan cuci kaki setelah beraktifitas, dan membiasakan anak buang sampah pada tempatnya, Orang tua memperhatikan kesehatan anaknya dengan memeriksakannya secara rutin ke Puskesmas atau ke Klinik kesehatan anak, Orang tua sangat perduli terhadap kesehatan anaknya dengan terus menjaga kebersihan fisik anak dan kebersihan leingkungan sekitar anak, d) Orang tua memeperhatikan kesehatan anak melalui pengaturan jam istirahat bagi anak; (c) Meningkatnya pemahaman orang tua tentang perawatan anak, hal ini dapat dilihat dari sikap orang tua yang lebih memperhatikan perawatan pada anak dengan menerapkan pola hidup bersih pada anak, Orang tua juga semakin perduli terhadap kebersihan fisik anak, di antranya orang tua bisa menjaga kebersihan rambut, kuku, gigi, tangan dan kaki anaknya; (d) Meningkatnya pemahaman orang tua tentang pengasuhan anak, hal ini dapat dilihat dari : Semakin perdulinya orang tua terhadap tumbuh kembang anak, Orang tua juga dapat mengatur waktu anak, dan mengatur pola makan anak supaya anak tetap sehat, Orang tua dapat memposisikan diri menjadi contoh bagi anaknya, Orang tua selalu mengajarkan anak tentang pentinga kejujuran, kerjasama, disiplin, dan tanggung jawab, Orang tua memahami betapa pentingnya menanamkan nilai kesopanan pada anak, misalnya menghargai orang tua dan guru, Orang tua sudah menerapakan pengasuhan 
yang sesuai dengan usia anak, dengan tidak terlalu mengekang anak, dan Orang tua dapat melakukan pengasuhan yang efektif dengan memperhatikan quality time; (e) Menigkatnya pemahaman orang tua tentang pendidikan, hal ini dilihat dari: Keperdulian orang tua terhadap pendidikan anaknya semakin meningkat, yakni orang tua menyiapkan sarana yang dibutuhkan untuk pendidikan anak di sekolah, orang tua dapat membimbing, mengawasi, dan menjadi teman belajar anaknya di rumah, dan orang tua aktif berkonsultasi dengan guru masalah pendidikan anak melalui SMS dan telfon, dan orang tua mau menjadi narasumber di kelas anak; dan (f) Meningkatnya pemahaman orang tua tentang perlindungan anak, hal ini terlihat dari: Kerelaan orang tua dalam memperbanyak waktu bersama dengan anak, Orang tua semakin proteks terhadap anaknya, Orang tua dapat meneerapkan lingkungan yang nyaman di rumah, sehingga anak betah tinggal di rumah, Orang tua lebih memperhatikan hak-hak anak dalam keluarga, seperti mendengar pendapat anaknya/tidak otoriter meskipun anaknya masih kecil, dan Orang tua tidak melakukan segala bentuk kekerasan fisik pada anak.

Hasil sebaran angket terkait dengan hasil program parenting pada lembaga PAUD disajikan dalam gambar Diagram berikut:

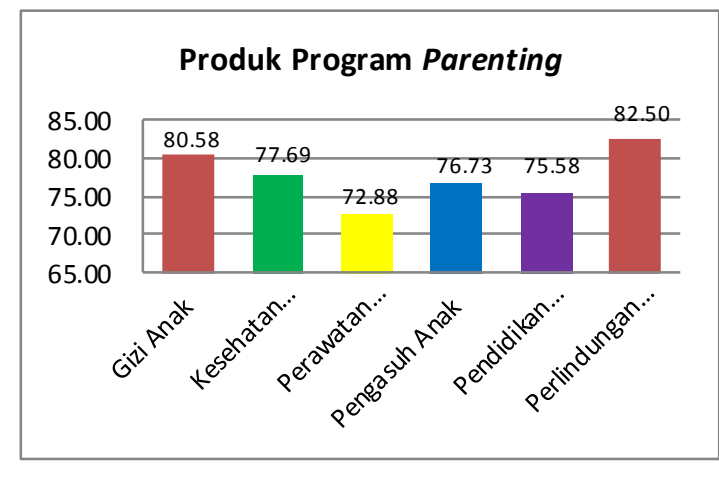

\section{Gambar 4}

\section{Diagram Hasil Program Parenting}

Hasil sebaran angket diketahui bahwa tingkat pencapaian produk pemahaman orang tua terkait dengan gizi anak 80,58\%, pemahaman orang tua terkait dengan kesehatan anak $77,69 \%$, pemahaman orang tua terkait dengan perawatan anak $72,88 \%$, pemahaman orang tua terkait dengan pengasuhan anak $76,73 \%$, pemahaman orang tua terkait dengan pendidikan anak $75,58 \%$, pemahaman orang tua terkait dengan perlindungan anak $82,50 \%$.

\section{KESIMPULAN}

Berdasarkan hasil analisis data terhadap evaluasi program parenting pada 12 lembaga PAUD di Kota Mataram, dapat ditarik kesimpulan sebagai berikut: Pertama, Pelaksanaan program parenting pada PAUD dilatarbelakangi oleh dua hal, yakni: (1) Landasan Formsl Pelaksanaan Program parenting adalah Undang Undang RI Nomor 20 Tahun 2003 tentang "Sistem Pendidikan Nasional" Bab 1 Pasal 1 Butir 14, Undang Undang RI Nomor 23 Tahun 2002 tentang "Perlindungan Anak" Pasal 9 Ayat 1, dan Permen Pemberdayaan Perempuan dan 
Perlindungan Anak RI Nomor 13 Tahun 2010 Tentang "Petunjuk Teknis Kabupaten/Kota Layak Anak di Desa/Kelurahan"; (2) Pada sebagian besar lembaga PAUD partisipasi orang tua terhadap pendidikan anak masih rendah, dan antara orang tua dengan guru perlu terjalin semacam kerjasama kedua belah pihak; Kedua, Pelaksanaan pogram parenting pada lembaga PAUD secara umum telah memenuhi syarat sesuai yang digariskan pada buku petujuk teknis, di mana dalam pelaksanaan program parenting dilakukan beberapa tahapan, yakni menetapkan tujuan, menetapkan sasaran, menetapkan bentuk pengelolaan program, menetapkan bentuk pendekatan yang akan digunakan, menetapkan bentuk program, menyiapkan narasumber, bersedia menerima pendampingan dari lembaga terkait, mengoptimalkan peran lembaga PAUD dalam menunjang pelaksanaan program, menyiapkan metode, media dan materi yang akan diberikan dalam program; Ketiga, Pelaksanaan program parenting pada lembaga PAUD telah dilakukan sesuai buku pedoman, yakni; terlebih dahulu melakukan sosialisasi kepada orang tua, pembentukan pengelola program, melakukan penyamaan persepsi, melakukan identifikasi kebutuhan belajar, membuat kesepakatan dengan orang tua terkait dengan tempat dan waktu kegiatan, menyusun program dan jadwal kegiatan, terlaksananya pertemuan orang tua, orang tua terlibat dalam beberapa hal seperti: kelas orang tua-anak, acara bersama, hari konsultasi, dan kunjungan rumah; Keempat, Hasil pelaksanaan program parenting pada sebagian besar lembaga PAUD menunjukkan bahwa pemahaman orang tua semakin baik mengenai gizi, kesehatan, perawatan, pengasuhan yang bermutu, penddidikan yang baik, dan perlindungan.

\section{REKOMENDASI}

Berdasarkan hasil evaluasi pelaksanaan program parenting pada 12 lembaga PAUD di Kota Mataram, dapat dikemukakakn beberapa rekomendasi sebagai berikut: (1) Perlu menghadirkan narasumber dari luar dengan cara menjalin hubungan kerja sama dengan Dinas Dikpoda dan lembaga terkait lainnya; (2) Perlu kiranya instansi terkait memeperhatikan lembaga tersebut, terutama oleh dinas Dikpora; (3) Perlu diperhatikan lagi oleh lembaga PAUD yang melaksanakan program parenting, karena semakin variatif metode yang digunakan akan semakin banyak pengalaman belajar yang diperoleh oleh peserta program; (4) Perlu dipersiapkan sejumlah media sehingga materi parenting dapat diterima orang tua dengan maksimal; (5) Pengelola parenting pada lembaga PAUD harus melakukan penyamaan persepsi untuk efesiensi dan efektifitas keberhasilan program; (6) Upaya identifikasi kebutuhan belajar bagi orang tua masih perlu dilakukan pada bebrapa PAUD yang melaksanakan program parenting, supaya apa yang direncanakan oleh pengelola dapat 
terlaksana dengan baik; (7) Pengelola program harus melibatkan orang tua dalam menentukan tempat dan waktu kegiatan; (8) Pihak pengelola harus melibatkan orang tua dalam penyusunan program; (9) Perlu bagi pengelola program parenting menghimbau kepada orang tua agar setiap kegiatan pertemuan penting untuk diikuti; (10) Penting bagi pengelola melibatkan orang tua secara maksimal dalam kelas anak; (11) Pengelola harus memprogramkan kunjungan rumah, mengingat kegiatan ini dapat mempererat silaturrahmi antara guru dan orang tua siswa; (12) Pengelola harus meningkatkan himbauan kepada para orang tua; (13) Perlu bagi pengelola untuk lebih giat lagi dalam menyadarkan orang tua, hal yang mungkin dilakukan adalah mendatangkan narasumber dari kesehatan; dan (14) Perlu bagi pengelola untuk lebih giat lagi dalam mensosialisasikan tentang pola pengasuhan yang baik kepada orang tua, hal yang mungkin dilakukan adalah mendatangkan narasumber terutama psikolog dan tokoh agama.

\section{DAFTAR RUJUKAN}

Andayani, Budi dan Koentjoro. Peran Ayah menuju Coparenting. Sidoarjo: Laras, 2012.

Basya, Hasan Syamsi, Mendidik Anak Zaman Kita terjemahan Muhammad Zaenal Arifin. Jakarta: Zaman, 2011.

Departemen Agama Ri, Al Qur'an dan Terjemahannya. Bandung: Diponegoro, 2006.
Gichara, Jenny. Mendidik Anak Sepenuh Jiwa. Jakarta: PT. Elex Media Komputindo Kelompok Gramedia, 2013.

Kementrian Pendidikan Nasional, Pedoman Penyelenggaraan Pendidikan Berbasis Keluarga. Direktorat Pembinaan Pendidikan Anak Usia Dini, DITJEN PAUDNI, 2012.

Kemetrian Pendidikan Nasional, Petunjuk Teknis Penyelenggaraan POS PAUD. Direktorat Pembinaan Pendidikan Anak Usia Dini, DITJEN PAUDNI, 2011.

Megawangi, Ratna. Pendidikan Karakter Solusi Yang Tepat Untuk Membangun Bangsa, Jakarta: Star Energi, 2004.

Razak, Roni Noe'man, Amazing Parenting. Menjadi Orang Tua Asyik, Membentuk Anak Hebat! Jakarta Selatan: Noura Books, 2012.

Shohib, M., Pola Asuh Orang Tua, Jakarta: Rineka Cipta, 1998.

Thoha Chabib, Kapita Selekta Pendidikan Islam, Yogyakarta: Pustaka Pelajar, 1996. 